\author{
Alcileide Cabral do Nascimento \\ Universidade Federal Rural de Pernambuco
}

\title{
O bonde do desejo: o Movimento Feminista no Recife e o debate em torno do sexismo (1927-1931)
}

Resumo: Este artigo investiga como o Movimento Feminista em Recife problematizou o silêncio e a negação dos direitos políticos às mulheres na Primeira República. Estrategicamente, as feministas tiveram como foco a conquista dos direitos políticos, como possibilidade de alcançar a igualdade civil e os direitos sociais. A intensa utilização da imprensa, do rádio e a criação de jornais e revistas pelas feministas falam de práticas de liberdade e de jogos de poder que buscam redefinir as relações de gênero nos marcos do regime republicano e democrático. Se - Movimento não combateu a naturalização da diferença entre os sexos, questionou seus pressupostos e desnudou a profunda e entranhada concepção de inferioridade das mulheres diante dos homens. As feministas pegaram o moderno bonde e fizeram os percursos do desejo. Palavras-chave: feminismos; Movimento Feminista; relações de gênero; cidadania.

Copyright (c) 2013 by Revista Estudos Feministas.

' Nicolau SEVCENKO, 1998, p. 515516.
Os anos iniciais do regime republicano dão asas aos desejos, fazem voar sonhos. A vida urbana ganha intensidade, luz, fluidez e velocidade. As novidades se espraiam pelas avenidas e pelos becos das grandes cidades. A eletricidade, o cinema, o automóvel, a locomotiva, o bonde, o avião, a publicidade, a moda, o relógio, o telefone, o rádio, os alimentos enlatados, os novos medicamentos e cosméticos, os cigarros e charutos industrializados, a prática de esportes, os banhos de mar, as confeitarias que se instalam em nobres endereços e as artes plásticas dão visibilidade a essas mudanças vertiginosas e de feições tão modernas.

A cidade é um espetáculo a céu aberto. Se, de um lado, essas novidades geram fé e otimismo no progresso, por outro, desorientam, intimidam, perturbam, confundem, distorcem, alucinam. ' Nesse cenário, as mulheres parecem gozar de maior liberdade, ao usufruir dos cafés, cinemas, da moda e das novas formas de sociabilidade. No entanto, sobre esse novo comportamento, pairam temores antigos e modernos de que esse 'excesso de liberdade' corrompa os cuidados com o 
${ }^{2}$ Pesquisa financiada pelo $\mathrm{CNPa}$ e pela FACEPE. lar, coloque em perigo a família e a honra feminina. Ademais, algumas mulheres, oriundas da classe média e alta, alçam outros voos para além do lar. Acadêmicas, médicas, advogadas, professoras e funcionárias públicas são algumas das profissões que empoderam o sexo feminino, abrem horizontes e novos questionamentos nas relações de gênero e na esfera política, da qual elas se encontram excluídas.

O problema, que já se coloca nos anos iniciais do regime republicano, é a estreiteza com que se compreende a cidadania e a noção de esfera pública moderna, na vigência da 'república dos coronéis', na qual só votam homens, maiores de 21 anos e alfabetizados, em eleições duvidosas. Afinal, onde reside a diferença entre homens e mulheres que alimenta a exclusão feminina da arena política? Esse parece ser 0 ' $x$ ' da questão colocada por diferentes feministas do Recife e de outras capitais, onde as mulheres discutem, debatem e questionam sua exclusão dos espaços públicos de decisões políticas.

A partir disso, neste artigo, ${ }^{2}$ averiguo os argumentos das feministas pernambucanas em prol da igualdade de direitos políticos, que passavam pelo questionamento da diferença entre homens e mulheres, e tinham como base o problema que a democracia republicana instaurou, ao abolir o voto censitário e criar a divisão sexual na esfera política. Também, avalio a estratégia política do movimento sufragista que, se de um lado objetivou a emancipação das mulheres de forma pacífica, por outro, atiçou o desejo feminino, ao almejar mais do que o direito de votar e de concorrer a votos.

\section{Em nome do desejo: os direitos políticos nas vozes das mulheres}

As mulheres, assim como os homens, nascem membros livres e independentes da espécie humana, dotados de faculdades equivalentes e igualmente chamados a exercerem, sem peias, os seus direitos e deveres individuais. ${ }^{3}$

120.

${ }^{4} \mathrm{~A}$ Declaração dos Direitos da MuIher é inspirada na Declaração dos Direitos da Mulher e da Cidadã que a feminista Olympe de Gouges encaminhou à Assembleia Nacional da França em 1791 para que fosse aprovada, numa clara crítica à Declaração dos Direitos do Homem e do Cidadão. Cf. Declaração dos Direitos da Mulher e da Cidadã (In: INTHERTESIS, 2012).

${ }^{5}$ Sobre o debate no Congresso da validade ou não do voto feminino no Rio Grande do Norte, ver ALVES, 2000, p. 117-121.
É assim que as sufragistas filiadas à Federação Brasileira para o Progresso Feminino se manifestam revoltadas e indignadas com a decisão do Senado de depurar os votos das eleitoras norte-rio-grandenses que haviam votado pela primeira vez em 1927 - e lançam a Declaração dos Direitos da Mulher, ${ }^{4}$ conclamando as mulheres para exercer 'sem peias' a cidadania política. ${ }^{5}$ São os novos tempos, com aspirações, sonhos, inquietações e frustrações. Sim. Frustrações datadas, inclusive, quando as mulheres foram devidamente 'esquecidas' e silenciadas na Constituição de 1891, que estabeleceu o sexismo político, 
${ }^{\circ}$ June HAHNER, 2003.

7 SCOT, 2002, p. 48.

${ }^{8}$ Michel FOUCAULT, 2004, p. 267.

9 Ver Céli Regina PINTO, 2002, p. 15-16.

${ }^{10}$ Anne Verfus, 2005, p. 428, grifo da autora.

1 VERFUS, 2005, p. 430. ao sancionar que apenas homens alfabetizados seriam considerados cidadãos.

É uma data para se execrar e exaltar ao mesmo tempo. Se as mulheres já se pronunciavam sobre seus direitos e desejos, já se imiscuíam na campanha abolicionista, ousavam publicar revistas e periódicos, como mostra o estudo de June Hanher, ${ }^{6}$ a lei republicana, portanto, foi mesmo excludente, ao não considerar a mulher como cidadã. Assim, podese dizer que a data é execrável, mas, ao dar visibilidade à disparidade entre os sexos, termina por fortalecer as reivindicações feministas e os movimentos feministas. Nesse sentido, a afirmação de Joan Scott de que "o feminismo não é produto das operações benignas e progressistas do individualismo liberal, mas um sintoma de suas contradições", 7 ganha força também no Brasil.

Não há dúvida de que no país os movimentos feministas tomam fôlego na Primeira República, regime oligárquico e liberal, como se sabe. Mas isso só é possível nos marcos de um Estado que se propõe a ser democrático, onde a liberda-de é um dos princípios norteadores de sua constituição. E as mulheres instrumentalizaram esse espaço da liberdade e da crítica. A intensa utilização da imprensa, do rádio e a criação de jornais e revistas pelas feministas falam, por si, de novas práticas de liberdade ${ }^{8}$ e de deslocamentos de jogos de poder. Provocam, questionam, apontam caminhos de convivência entre os sexos, redefinindo campos de relações de poder entre os gêneros, descortinando novos horizontes para mulheres e homens.

Na Constituição republicana, o direito de votar não é explicitamente negado à mulher. Aliás, sequer a mulher é citada, já que os constituintes entendiam que a mulher não é um sujeito possuidor de direitos, como a historiografia vem enfatizando. ${ }^{9}$ Contudo, o dado novo no debate é a questão colocada por Anne Verfus, ao aclarar que "a cidadania oriunda da abolição do sufrágio censitário fez emergir com uma visibilidade sem precedentes a separação política entre os homens e as mulheres", 10 ao fazer aparecer o voto individual masculino em 'idade viril' e a não inclusão das mulheres no corpo eleitoral. O sexismo, que, como princípio político, faz uso do discurso da diferença natural entre os sexos para justificar as desigualdades em matéria de direitos políticos, ${ }^{11}$ torna-se um problema para o regime republicano brasileiro e vira bandeira de luta dos movimentos feministas, que dão seus primeiros passos no território nacional e em outras partes do mundo. Em Recife, a conquista dos direitos políticos pelas feministas do Rio Grande do Norte, em 1927, coloca o tema na ordem do dia, e algumas mulheres são chamadas a expressar opinião sobre essa vitória feminista na vizinha província. 


\section{Uma enquete para dar o que falar}

${ }^{12}$ A NOTíCIA, 7 nov. 1927.

${ }^{13}$ A NOTícIA, 14 dez. 1927.

${ }^{14}$ A NOTíCIA, 15 dez. 1927.

${ }^{15}$ A NOTíCIA, 15 dez. 1927.
Em artigo de 7 de novembro de 1927, o jornal A Notícia informa que, no dia 31 de outubro desse mesmo ano, foi aprovado pela Assembleia Legislativa do Rio Grande do Norte o direito das mulheres de votar, dando exemplo ao país, ainda que a imprensa brasileira não tenha dado a merecida repercussão a essa conquista. Segundo o jornal, "é uma inovação ousada que os rio-grandenses introduzem em nossos costumes políticos, adiantando-se à própria união que ainda não se resolveu entregar seus destinos às mãos das mulheres". ${ }^{12}$

Em outra matéria, o jornal afirma que a discussão do voto feminino supera até mesmo as contendas em torno do voto secreto. Por ser assunto polêmico, o jornal se propõe a fazer uma enquete sobre o tema com "intelectuais e figuras prestigiadas" da sociedade, e abre o debate com a seguinte pergunta: "É bom ou mau o voto feminino?"13

Da enquete prometida, são entrevistadas a poetisa Anna Amélia C. de Mendonça, a escritora D. Rachel Prado e D. Esther do Rego Barros, esposa do então presidente da Câmara dos Deputados. Essa primeira questão trata do direito das mulheres ao voto. Anna Amélia, embora afirme não ter "opinião amadurecida" sobre a questão, que considera "complexa e transcendente", problematiza o direito ao voto do ponto de vista da democracia e da igualdade entre os sexos. Em consonância com o princípio fundamental que diz que "o melhor meio de governar os povos é fazer política partidária", sua argumentação a favor do voto feminino está na assertiva de que, "desde que o voto existe, deve esse direito caber, como todos os direitos políticos, igualmente a ambos os sexos", portanto, sem distinção. ${ }^{14}$

A poetisa também entra no debate sobre o valor e a eficiência do voto feminino. Sem dúvida, considera que é preciso avaliar "o grau de cultura feminina no Brasil para poder concluir em que percentagem está ela [a mulher] verdadeiramente preparada para o voto", mas adverte que também nem todos os homens estão preparados para exercer esse direito, e questiona: "Quantos não o estão fazendo dentro da mais absoluta incompetência, capazes apenas de escrever um nome, inconscientes da própria responsabilidade!". ${ }^{15}$

Nessa linha de argumentação, a escritora Rachel Prado ataca os que subestimam as mulheres, quando insistem em que elas não saberiam usar o direito de voto, e lembra aos incautos e "pessimistas" que, para "legislar ou ditar leis inócuas ou progressistas, não são chamados todos os homens coletivamente". Há uma elite para isso no Legislativo e no Executivo, "representantes das massas e ou das 'aspirações

44 Estudos Feministas, Florianópolis, 21 (1): 41-57, janeiro-abril/2013 
${ }^{16}$ A NOtícIA, 27 dez. 1927.

${ }^{17}$ Norberto BOBBIO, 2000, p. $371-$ 386.

${ }^{18}$ A NOTíCIA, 15 dez. 1927.

${ }^{19}$ A NOTíCIA, 15 dez. 1927.

${ }^{20}$ A NOTíCIA, 27 dez. 1927.

${ }^{21}$ A NOTíCIA, 27 dez. 1927.

${ }^{22}$ A NOTíCIA, 27 dez. 1927.

${ }^{23}$ A NOTí́CIA, 27 dez. 1927. públicas'", 16 no que tinha razão. Não são as massas que governam nem decidem, mas seus representantes, como esclarece Bobbio sobre os princípios que norteiam a democracia. ${ }^{17}$

A terceira questão do debate elencada pelo periódico é: Até que ponto o voto feminino é compatível com a vida do lar? Nesse aspecto, as entrevistadas seguem a forte tendência de reafirmar a responsabilidade das mulheres com o lar e os filhos como "deveres verdadeiramente femininos". Ao mesmo tempo, Anna Amélia argumenta que, muito mais do que o ato de votar, afastam-nas de seus lares "a intensa vida mundana e os intermináveis compromissos sociais da vida moderna nas cidades". ${ }^{18}$ Sua fala remete à dimensão de classe. Aqui ela não se reporta às mulheres trabalhadoras, operárias, diaristas, às que precisavam ganhar o pão de cada dia, mas às que curtiam o lazer, o consumo e as novas sociabilidades da vida moderna, e recusavam, negavam veladamente a vida doméstica e a domesticidade de suas vidas. Por fim, Anna conclui que, "com ou sem direito ao voto, a mulher terá sempre a responsabilidade no futuro da sua pátria, quando ostentar nos braços uma parcela viva do porvir: um filho". ${ }^{19}$ Procriar seria, portanto, sua contribuição para a nação, responsabilidade inscrita em sua natureza, em seu corpo, em sua essência, e da qual nenhum direito político poderia isentá-la.

Já Rachel Prado, mais eloquente em suas assertivas, reafirma a missão natural da mulher "cônscia dos seus deveres, como orientadora e responsável pelo futuro dos filhos, que seriam úteis à família, à Pátria e à Humanidade". ${ }^{20}$ Mas não se trata de qualquer mulher. Encontra-se aqui uma reivindicação de classe: a educação feminina, pois, para ela, "só a mulher inteligente e culta saberá preparar homens nobres para uma pátria grandiosa", ${ }^{21}$ deixando de ser "melindrosa e fútil", "instrumento de prazer" e "objeto de luxo" dos homens. Portanto, Rachel reivindica outro lugar para as mulheres, que extrapola os muros do lar. Para essa escritora, "a mulher deve ser, em qualquer país, uma unidade econômica, independente, e só o será quando de posse de seus direitos políticos". ${ }^{22}$ Essa questão é basilar para várias das feministas de então: a autonomia econômica feminina diante do poder dos homens. Nesse sentido, não se vê o homem como superior ao sexo feminino, mas como um companheiro emancipado ao lado da mulher. Depois de afirmar que mais de trinta e tantos países civilizados já tinham dado a igualdade de direito às mulheres, ela alfineta a elite brasileira, ao declarar que o "Brasil não quererá fazer um papel retrógado, inclinado ao preconceito todo de que o lugar da mulher é única e exclusivamente no lar". ${ }^{23}$ Esther de Rego Barros, senhora da elite pernambucana, coloca-se contrária ao voto feminino, porque entende que a 
${ }^{24}$ A NOTíCIA, 28 dez. 1927.

${ }^{25}$ A NOTÍCIA, 28 dez. 1927. grande missão social da mulher é "a formação do caráter dos filhos, que se molda numa educação inspirada nos sãos princípios de moral católica". ${ }^{24}$

Assume posição declaradamente antifeminista, ao desconsiderar as possibilidades de mudança e conquistas derivadas desse direito, sobretudo, porque entende que, na organização familiar vigente, "a grande maioria das mulheres não tem ainda independência, para intervir nos acontecimentos políticos, com a necessária autonomia". Assim, em sua apreciação, a reforma política com a inclusão das mulheres não deveria "ser fonte de inquietação" da "comunhão brasileira". ${ }^{25}$ Essa opinião parece expressar consenso sobre o voto feminino: seus deveres para com o lar; sua dependência, portanto, a pouca autonomia para escolher e votar; e, por fim, uma vez sendo concedido o direito, este não traria maiores transtornos ao status quo, já que os alicerces desiguais das relações de gênero não seriam alterados. O poder patriarcal continuaria intacto e as mulheres, submissas ao lar, aos maridos, aos pais, aos homens.

O que se vê, portanto, são diferentes opiniões. O que as une é a certeza de que existia uma natureza feminina inscrita no corpo, na capacidade e na obrigação de procriar e educar. Se, para Anna Amélia e Rachel Prado, não há diferença entre homens e mulheres que fundamente a exclusão política, Esther de Rego Barros silencia sobre a exclusão da mulher da cidadania política e desloca a questão para a dependência econômica do sexo feminino, que derivaria da impossibilidade de exercer com autonomia esse direito, uma vez conquistado. Enquanto as duas primeiras defendem a compatibilidade entre a vida do lar e o direito político, a terceira termina por defender que a mulher deve concentrar-se em sua missão de mãe e esposa. Contudo, D. Esther acredita que a conquista das mulheres será inevitável, mas, com um olhar desencantado para a emancipação feminina, vaticina que isso não significaria maiores transtornos à sociedade, porque teria alcance transformador limitado.

O debate estava em aberto. O medo pairava no ar. A virilidade masculina parecia estar colocada em xeque. Uma guerra dos sexos se encenava, às vezes, veladamente; outras vezes, com cores e tons fortes. Mulheres educadas e formadas, de famílias abastadas, reclamavam de sua sujeição e, de certa forma, davam visibilidade ao sexismo da política republicana que, ao acabar com o voto censitário, revelou o quão menosprezava a força, a inteligência e a capacidade femininas, independentemente de sua condição social e civil. Ricas, pobres e remediadas, casadas ou solteiras, as mulheres pareciam carregar consigo a pecha de inferioridade, a quem se negava a vida política.

46 Estudos Feministas, Florianópolis, 21 (1): 41-57, janeiro-abril/2013 
${ }^{26}$ Martha de Hollanda, em 31 de maio de 1931, reuniu em sua casa um grupo de mulheres da elite $e$ da intelectualidade pernambucana. Nessa ocasião, elas criaram a Cruzada Feminista Brasileira elegeram a diretoria, definiram os principais objetivos e declararam sua filiação à FBPF (Cf. A NOTíCIA, 31 maio 1931). Em 12 de novembro daquele mesmo ano, foi empossada a diretoria: presidente, Martha Hollanda; vice-presidente, Auri Moura; oradora, Heloísa Chagas; oradora adjunta, Juracy Soes; primeira secretária, Celeste Dutra; segunda secretária, Jacyra Goes; tesoureira, professora Antônia Maranhão; bibliotecária Silvia do Passo; procuradoras, farmacêutica Antônia Martins $e$ professora Edmée Barbosa (Cf. A NOTíCIA, 12 nov. 1931). Nem Martha de Hollanda aceitou o convite de participar da Federação Pernambucana criada por Edwiges e, tudo indica, Edwiges de Sá declinou do convite de ser presidente de honra da Cruzada Feminista, fundada por Martha (Cf. A NOTíCIA, 31 maio 1931).

${ }^{27}$ A NOTÍCIA, 31 maio 1931.

${ }^{28} \mathrm{~A}$ confirmação de que essa reunião aconteceu na casa da Edwiges está n'A Notícia, de 2 junho de 1931

${ }^{29}$ A NOTíCIA, 31 maio1931.

30 ARQUIVO NACIONAL..., 1931 .

1933 , p. 3

${ }^{31}$ ARQUIVO NACIONAL..., 1931-

1933, p. 2.

${ }^{32}$ A NOTíCIA, 2 jun. 1931.

\section{Nas asas do desejo: a criação da Federação Pernambucana para 0 Progresso Feminino}

As notícias sobre as conquistas femininas circulam na capital pernambucana, como visto. Os jornais, aqui e acolá, trazem os últimos debates e embates no Congresso em torno das reivindicações feministas pelo direito ao voto, nas mobilizações no Rio de Janeiro, epicentro político do movimento, liderado pela jovem feminista Bertha Lutz. Em Recife surgem, em 1931, duas organizações que pretendem lutar pelos direitos das mulheres: uma representada por Martha de Hollanda ${ }^{26}$ e outra por Edwiges de Sá Pereira, duas expressões importantes no cenário intelectual da cidade como poetisas e escritoras. Contudo, o enfoque aqui será dado à Federação Pernambucana para o Progresso Feminino (FPPF), não apenas por ser filiada à Federação Nacional, mas pela visibilidade que teve em Pernambuco.

Marcada pelas incertezas de qualquer começo, com caminhos árduos a desbravar, "a resistência do hábito, os percalços do preconceito, a indiferença pela causa, o negligente desconhecimento do que ela importa como a expressão mais elevada da justiça", como desabafa a presidente da Federação Pernambucana, em seu primeiro relatório, tinha início a organização das feministas. Esse movimento teve mais visibilidade em prol dos direitos políticos para as mulheres, filiado ao movimento nacional de linha moderada e elitista, que buscava ampliar os marcos delimitadores da República brasileira liberal, de feição burguesa e base ruralista, falocêntrica e profundamente excludente. Em síntese, a luta tinha um foco: emancipar o sexo feminino, a partir da plataforma dos direitos - cidadania política, educação primária obrigatória, igualdade civil com os homens, legislação trabalhista protetora da mãe e da criança.

Em 31 de maio de 1931, Edwiges de Sá Pereira fez um convite, por meio do periódico $A$ Notícia, às "senhoras pernambucanas que se interessam pela reivindicação dos direitos femininos"27 para uma reunião em sua casa, na Boa Vista, rua do Progresso, n. $71,{ }^{28}$ cujo objetivo era "fundar em Pernambuco uma associação" filiada à Federação Brasileira para o Progresso Feminino (FBPF), "sob as mesmas bases e com idênticos propósitos". ${ }^{29}$ Edwiges informava que fazia essa convocação na condição de delegada da FBPF. Nessa reunião, com a presença de trinta senhoras, ${ }^{30}$ foi nomeado um comitê de propaganda, que divulgaria as atividades do grupo pela imprensa e pelo rádio, ${ }^{31}$ foi lida uma carta da escritora Martha de Hollanda, "justificando sua ausência por motivos imprevistos" e foi agendada uma nova reunião. ${ }^{32}$ 
${ }^{33}$ A NOTíCIA, 7 jun. 1931.

${ }^{34}$ ARQUIVO NACIONAL..., 19311933, p. 3.

${ }^{35}$ Sabe-se dessas informações quando se cruzam as assinaturas das atas das sessões extraordinárias da Federação Pernambucana para o Progresso Feminino (acervo FUNDAJ, Recife) e de algumas articulistas que colaboravam na Revista Pernambucana (Recife, 1902) e Polyantho (Recife, 1904). 36 ARQUIVO NACIONAL..., 19311933, p. 2.

${ }^{37} \mathrm{O}$ político pernambucano Carlos de Lima Cavalcanti foi designado por Juarez Távora para assumir o governo como interventor do estado, depois da Revolução de 1930. Ele era coproprietário da Usina Pedrosa e dos jornais Diário da Manhã e Diário da Tarde. Também era considerado um político tradicional, ligado à velha oligarquia açucareira. Segundo Manuel Correia, Cavalcanti "não tinha uma linha ideológica segura e se cercou de pessoas de posições político-ideológicas as mais diversas", de forma que os problemas não tardaram a aparecer, como o levante dos insatisfeitos tenentes (Cf. Manue Correia ANDRADE, 1997, p. 335337).

${ }^{38}$ Antônio Paulo REZENDE, 2002,

p. 106.

${ }^{39}$ ANDRADE, 1997, p. 337

${ }^{40}$ A NOTíCIA, 6 nov. 1931

${ }^{41}$ A NOTíCIA, 31 nov. 1931.
O comitê de propaganda entrou em campo para a organização da filial pernambucana. Na segunda reunião, compareceu "avultado número de senhoras", com apoios importantes, como da educadora D. Débora Feijó e da acadêmica Ida Uchôa - que, segundo evidências indicam, deixou a Cruzada Feminista Brasileira e se filiou à Federação Pernambucana. ${ }^{33}$ As mulheres reuniram-se ainda algumas vezes na casa da jovem escritora e professora Edwiges de Sá Pereira. ${ }^{34}$ Quem eram essas mulheres? O que pretendiam? Como levariam a cabo a vontade impetuosa de tornarem-se cidadãs? Como engajar-se na luta sufragista? Qual era o alcance dos objetivos? Que obstáculos encontrariam no caminho? Como enfrentar a vasta e disseminada corrente antifeminista?

Escritoras, poetisas, advogadas, professoras, irmãs de Edwiges, moças de famílias importantes, como Celina Feijó, Ignez Sabino, Maria Augusta Meira Vasconcelos Freire, Nanette de Sá Pereira, Umbelinda Bandeira, Amélia Bivilaqua, Dulce Chacon, atenderam ao chamado da feminista. Mulheres de classe média, educadas, algumas profissionais liberais, casadas e solteiras compareceram às reuniões e foram responsáveis pelo sucesso da iniciativa. ${ }^{35}$

A Federação Brasileira foi o grande suporte da filial pernambucana, inclusive pelos estreitos laços de amizade entre as duas lideranças feministas, como se observa nas cartas entre Bertha e Edwiges. Seguindo orientação da Nacional, nesses encontros, que deram origem à criação da sucursal pernambucana, foram discutidos os princípios e objetivos da associação; foi constituída a comissão organizadora; definida a participação de Edwiges de Sá como representante de Pernambuco para o II Congresso Internacional Feminista; feita a leitura do anteprojeto do estatuto; e, finalmente, no dia 2 de agosto, foi eleita a diretoria efetiva, por meio do voto secreto, e aclamadas as comissões subsidiárias para o conselho social, conselho auxiliar e conselho fiscal. ${ }^{36}$

A solenidade de abertura foi marcada para o dia 31 de outubro. No entanto, o levante dos jovens tenentes do $21^{\circ}$ Batalhão de Caçadores no Recife contra o governo de Carlos de Lima Cavalcanti, ${ }^{37}$ que contou com a adesão de parte da população, ${ }^{38}$ sacudiu a cidade durante três dias, com a ocupação de quartéis e algumas delegacias de bairros, ${ }^{39}$ e provocou adiamento da criação oficial da associação feminista para o dia 10 de novembro. ${ }^{40}$

O surgimento da Federação Pernambucana não foi ato silencioso. A posse da diretoria aconteceu no prestigiado Club Internacional do Recife, pomposo endereço da cidade. O smart set recifense ali estava, como declarava A Notícia. ${ }^{41}$ Autoridades estaduais e federais, representantes da 
${ }^{42}$ ARQUIVO NACIONAL..., 19311933, p. 2.

${ }^{43}$ A NOTÍCIA, 11 nov. 1931.

${ }^{44}$ Cf. Rachel SOIHET, 2006, p. 29 ${ }^{45}$ Sobre os movimentos sufragistas na Inglaterra e Estados Unidos, conferir Branca Moreira ALVES Jacqueline PITANGUY, 1985, p. 4248 .

${ }^{46}$ A NOTÍCIA, 11 nov. 1931.

47 PEREIRA, 1932, p. 4.

${ }^{48}$ A NOTÍCIA, 11 nov. 1931.

${ }^{49}$ A NOTÍCIA, 11 nov. 1931.

50 PERROT, 2005, p. 281 imprensa e embaixadas das diversas corporações prestigiaram a solenidade. ${ }^{42}$ Foi um acontecimento, com a presença da imprensa, de famílias importantes, autoridades civis, legitimado pela condução da representante nacional Odila Porto da Silveira.

Em seu discurso de posse, a feminista pernambucana mostrou a via pacífica, moderada, que pretendia seguir, além de enfatizar seu apego aos princípios católico-cristãos, em um misto de "consciência, coragem e fé". Nesse sentido, ela esclareceu que "o que se pretende não é inovação nem importa em medidas que possam trazer qualquer alteração prejudicial aos bons princípios que norteiam os nossos costumes de família cristã". ${ }^{43}$ Esse tom amistoso e pacificador remete ao que foi usado por Bertha Lutz, quando afirmava que o movimento feminista não pretendia "uma associação de 'sufragettes', que ameaçassem quebrar vidraças da Avenida", ${ }^{44}$ em clara referência e recusa às formas de luta e embates das feministas inglesas. ${ }^{45}$

Apesar de anunciar as bases conciliadoras e conservadoras do movimento que presidia, a feminista pernambucana afirmava com convicção que "o lar é o refúgio do par humano", ${ }^{46}$ não apenas da mulher. Ademais, lembrava que nem todas podiam escolher ficar no lar; havia as que precisavam trabalhar. ${ }^{47}$ Mas também acusava de egoístas as que se enclausuravam e se negavam "a cooperar no socorro aos mais fracos", fugindo das obras pias e beneficentes. ${ }^{48}$ Edwiges, em consonância com 0 discurso de época de sua classe, atacava a ociosidade mundana das mulheres. Veladamente, recusava o papel de boneca de luxo, objeto de ostentação dos homens, mas também o ócio feminino e voyerismo citadino. Incitava-as a que saíssem dos lares: se forem "amparadas moral e materialmente pelo chefe da casa" e não queiram ou tenham profissão, que atuem socialmente, que sejam úteis. "Que repulse[m] as festas, que menospreze[m] as modas; que desdenhe[m] do footing", faces de sua educação vitoriana e católico-cristã ${ }^{49}$

No Brasil e alhures, o apelo ao trabalho social reforçava as qualidades tidas como naturais ao gênero feminino: dedicação, altruísmo, cuidados com o outro e elevada virtude moral. Mas, ao cuidar dos necessitados, a filantropia propicia às mulheres uma inserção pública e uma experiência que modifica a percepção do mundo e de gênero como sugere Michelle Perrot. ${ }^{50}$ Apesar de ser um trabalho gratuito, sem remuneração, e de não colocar em xeque a virtuosa esposa e mãe de família e nem afrontar economicamente 0 poder dos maridos, possibilitava às mulheres das camadas médias e altas transitar, sair, visitar domicílios pobres, ganhar as ruas e os becos insalubres da 
${ }^{51}$ PERROT, 2005, p. 279-280.

52 Jacques DONZELOT, 1986.

${ }^{53}$ Susan BESSE, 1999, p. 168.

${ }^{54}$ DIÁRIO DE PERNAMBUCO, 30 out. 1985.

${ }^{55}$ Semira VAINSENCHER, 2010.

${ }^{56}$ DIÁRIO DE PERNAMBUCO, 30 out. 1985.

57 Ângela de Castro GOMES, 2004, p. 7-24.

${ }^{58} \mathrm{Cf}$. Shuma SCHUMAHER e Érico Vital BRAZIL, 2000, p. 188-189. ${ }^{59}$ Segundo Margareth Rago, a Revista Feminina foi fundada por Virgilina Duarte da Costa e circulou, com bastante sucesso, entre os anos de 1914 e 1936, por todos os estados brasileiros. Embora rejeitasse o feminismo "revolucionário e anárquico", a revista fazia crítica à violência masculina, defendia "o direito ao voto e a educação das mulheres, sem que estas deixassem de ser a dona afetiva do seu lar" (RAGO, 1995/ 1996, p. 22). cidade. Era uma forma de serem "úteis" e de darem uma contribuição social, como defendia Edwiges de Sá. Descobriam outro mundo que parece inspirar uma "consciência de gênero", como assinala Perrot. ${ }^{51}$

Assim, o movimento feminista, liberal e comportado, ao se aproximar dos dramas, dos desafios, da luta diária das mulheres de vida simples, sem pompa ou fausto, parece dar mais força à educação feminina, seja para a conquista da autonomia financeira, seja para o bom desempenho da maternidade. Nesse sentido, o trabalho filantrópico amplia a problematização da exclusão feminina do campo político, visto como estratégico para conquista de outros direitos e oportunidades. Se para alguns autores/as, o trabalho dessas mulheres de classe média e alta servia para atenuar o conflito entre as classes e promover a ordem social, ${ }^{52}$ já que não questionava a hierarquia entre os gêneros, ${ }^{53}$ para outras/os era um espaço de reposicionamento pessoal e político. A própria Edwiges de Sá Pereira era um exemplo disso. No campo social, presidiu a Associação das Damas de Beneficência e integrou o Comitê Feminino da Maternidade do Recife. ${ }^{54}$

Quem era mesmo essa mulher que liderava a campanha sufragista em Pernambuco? Edwiges de Sá Pereira nasceu na cidade de Barreiros, em 24 de outubro de 1884, região da zona da mata sul de Pernambuco, produtora de cana-deaçúcar, de onde saiu um dos mais influentes políticos republicanos da tradicional elite açucareira, Estácio Coimbra. ${ }^{55}$ Filha do bacharel José Bonifácio de Sá Pereira e D. Maria Amélia Rocha de Sá Pereira, era de uma família de proeminentes juristas, como seu irmão Eurico de Sá Pereira, que chegou a ser presidente da Ordem dos Advogados do Brasil. ${ }^{56}$

Em relato autobiográfico de Edwiges, na perspectiva da escrita de $s i,{ }^{57}$ sem fissuras e rupturas, dúvidas ou incertezas, a autora constrói sua trajetória, que é marcada, desde o início, por forte relação com a literatura. Com apenas 13 anos, com a colaboração de seu irmão Eugênio, fez um jornal manuscrito, o Eco Juvenil. Um dia chegou-lhe, do Rio de Janeiro, o jornal O Paíz, contendo poemas seus do Eco, para sua grata surpresa. Em seguida, a Revista do Brasil, editada em São Paulo, publicou seu soneto intitulado $A$ uma estrela.

Aos 16 anos, lançou seu primeiro livro de poemas, intitulado Campesinas. Assim teve início uma carreira ascendente como poetisa e escritora, que lhe permitiria, ainda muito jovem, com 17 anos, ingressar na Academia Pernambucana de Letras, na condição de sóciacorrespondente ${ }^{58} \mathrm{~A}$ essa altura, já colaborava com diversos jornais no país, dentre eles, O Norte (Rio de Janeiro) e o Escrutínio (Rio Grande do Sul), e com revistas, como a Revista Feminina (São Paulo). ${ }^{59}$ 
${ }^{60}$ FUNDAJ. Notas Bio-bibliográficas de Edwiges de Sá Pereira. Acervo Pessoal. Recife, s/d.

${ }^{61}$ Sobre a sociedade vitoriana, ver Peter GAY, 1988.

${ }^{62}$ DIÁRIO DE PERNAMBUCO, 30 out. 1985.

${ }^{63}$ BRASIL, 1916.

${ }^{64}$ DIÁRIO DE PERNAMBUCO, 30 out. 1985.

${ }^{65}$ A NOTÍ́CIA, 11 nov. 1931.
Formou-se na Escola Normal, onde se tornou professora catedrática de História Geral e do Brasil. Assumiu também a Superintendência dos Grupos Escolares da Capital. ${ }^{60}$ Era uma mulher de fibra e "de contrastes", como assinalou seu sobrinho-neto Virgílio Campos, porque era muito avançada para sua época e, ao mesmo tempo, egressa de uma educação vitoriana, conhecida pela rigidez, pelo controle das emoções e da sexualidade. ${ }^{61}$ Era de um tempo, como remete seu sobrinho, "em que a rainha Vitória ditava a moda e o poder no mundo". 62

Todavia, fato que chama a atenção nas vidas das feministas, carioca e pernambucana, Bertha Lutz e Edwiges de Sá, é que não se casaram. O ingresso em um mundo masculino pela via da atividade intelectual e da militância política parece ter sido impeditivo ao casamento e à maternidade ou, talvez, isso tenha sido uma escolha. Ademais, a lei submetia a esposa ao marido. O Código Civil de 1916, no artigo 233, definia que "O marido é o chefe da sociedade conjugal. Compete-Ihe: [...] IV - O direito de autorizar a profissão da mulher e a sua residência fora do teto conjugal". ${ }^{63}$ É possível imaginar as implicações legais para essas mulheres se tivessem optado pelo casamento. A certa altura da vida, já com 70 anos, em conversa com as irmãs sobre o problema da mãe solteira, Edwiges revelou que "gostaria de ter tido um filho em qualquer circunstância", 640 que parece indicar uma vontade que independe de estar casada ou não. Mas, até onde se sabe, ela não se lançou nessa empreitada nem ousou contra a norma convencional e cristã católica a que declaradamente se filiava.

O programa que defendia, na solenidade de criação da Federação Pernambucana, implicava o direito da mulher de cultivar "a inteligência e especializar, se quiser e puder, a sua vocação no terreno científico"; auferir "dos seus conhecimentos as mesmas vantagens que o homem"; aspirar "para o seu trabalho remuneração ajustada ao serviço prestado sem atender [sem distinção] ao sexo". No discurso de Edwiges, essas reivindicações se alicerçam na seguinte percepção:

[...] a mulher uma vez que está sujeita, como o homem, ao censo, ao fisco, às contribuições, aos impostos, reclame garantias legislativas e práticas para o resultado do seu labor; porque a mulher pleiteie dentro do Código Civil a equivalência que lhe reconheceu o Código Penal; porque considerando a maternidade o seu mais elevado destino, se congreguem todos os que podem alguma coisa como inteligência, como atividade, como fortuna, uma ânsia de proteção e solidariedade, em torno das mães pobres ou moralmente desprotegidas... ${ }^{65}$

Estudos Feministas, Florianópolis, 21(1): 41-57, janeiro-abril/2013 
Discurso paradoxal. Há insatisfação latente e visível. Era injusta a condição em que se achava a mulher: pagar impostos, contribuir de diferentes maneiras como os homens, e não ter direitos iguais no campo civil e no político. Ser sujeitada, estar na dependência do marido, ser tratada como "menor" de idade e de razão. Seu discurso parece dissolver a diferença entre os sexos e considerá-la inaceitável. Ao mesmo tempo, entende a maternidade como "destino elevado" da mulher - não o seu -, para com a qual os poderes públicos deveriam ser mais solidários e protetores. Ao proteger e amparar a mãe pobre, cuida-se do futuro da nação, da prole que está em seus braços ou ventre. Seu posicionamento em relação à maternidade estava em chamar para o Estado a responsabilidade da proteção e de cuidados, da educação ao trabalho, de um amplo segmento da população, as mulheres pobres. A questão social era candente. A essa altura, não se podia mais acusar e apontar as mulheres das camadas populares como irresponsáveis. Seriam necessárias outras formas de atuação e posicionamento governamental. Ser pobre não é crime, e ser mulher pobre, menos ainda. O que se cobra do Estado é que amplie a gestão da população, sem divisar o custo da imposição dos tentáculos estatais - das normas, dos controles, da prevenção, das estatísticas, da rede múltipla de poder que enlaça a população e o indivíduo, que atinge as mulheres, penetra seus corpos e busca enquadrar suas práticas sexuais.

A estratégia que subjaz à fala de Edwiges é a de que os direitos políticos abririam caminho para os sociais e os civis. Porém, a seu ver, essa reivindicação não deveria provocar "receios" de "perturbação social", porque tudo seria feito "dentro dos limites do programa". Afinal, a mulher não pretendia tomar o lugar dos homens, como os incautos previam e diagnosticavam, porque, segundo a feminista, "cooperar não é usurpar, completar não é anular, substituir não é preterir. Bastar-se a si mesma dignamente, se eleva a mulher, não diminui o homem". ${ }^{66}$ Seu discurso parece propor a horizontalidade entre os sexos e a quebra da hierarquia fundada na superioridade masculina versus inferioridade feminina.

Ela era uma das que se bastavam a si mesmas: independente, profissional, inteligente e autônoma. Falava de um lugar social. Representava uma elite pensante e politicamente atuante. Embora não desejasse rupturas, ares revolucionários permeavam sua fala, no paradoxo em que se colocava o movimento feminista. Nesse sentido, seu discurso faz lembrar a revolucionária feminista francesa Olympe de Gouges, ao afirmar que "as mulheres só tinham paradoxos a oferecer" e, como assinala Joan Scott, "se, por 
${ }^{67}$ SCOT, 2002, p. 19.

${ }^{68}$ A emancipação econômica das mulheres é problema central para a $F B P F$, e reafirmado no $I I$ Congresso Internacional Feminista (Cf. SOIHET, 2006, p. 46)

${ }^{69}$ ARQUIVO NACIONAL..., 1931, p. 1 .

${ }^{70}$ ARQUIVO NACIONAL..., 1931, p. 1.

${ }^{71}$ ARQUIVO NACIONAL..., 1931, p.

2.

${ }^{72}$ ARQUIVO NACIONAL..., 1931, p.

2.

${ }^{73}$ ARQUIVO NACIONAL..., 1931, p.

2. um lado, pareciam aceitar definições de gênero como verdadeiras; por outro, elas as recusavam". ${ }^{67}$

Depois da fala de Edwiges, ainda na sessão de abertura da Federação, teve a palavra Cora Santa'Anna, representando a consultora jurídica da Federação, Dra. Ida Souto Uchôa, que estava enferma e não pôde comparecer à solenidade. No discurso da feminista Ida Souto, lido pela bacharelanda, ela declara que o principal objetivo da associação era a defesa das mulheres pela emancipação econômica e conquistas sociais. ${ }^{68}$ Entende que a evolução e a lei do progresso impõem um "estranho dinamismo" à vida, "grava em todas as coisas uma feição nova, diferentemente vertiginosa" 69 e, nesse ínterim, não faz sentido as mulheres não evoluírem, e continuarem a vida como plantas parasitárias, insuficientemente instruídas, vivendo na "eterna penumbra", porque "já vai longe o tempo em que a atividade da mulher girava unicamente em torno do lar"..$^{70} \mathrm{~A}$ força desse discurso ainda hoje impressiona. O novo se coloca como avassalador. O progresso chegará de forma implacável e deslocará a mulher do espaço do lar para outras veredas. Espíritos polidos e iluminados pela educação poderão gozar a plenitude dos desejos assegurados pela liberdade de escolha e de expressão.

Em sua concepção, o movimento feminista não visa a "masculinizar a mulher" nem quer que "grotescamente" ela imite o homem. O que se pretende é que seja sempre feminina, aja com "aspirações nobres" dentro e fora do lar, consciente de sua personalidade, integralizada na vida. Assim, saberá "inocular nos filhos a chama sagrada de beleza, de liberdade, de perfeição". ${ }^{71}$ Para isso, terá de se elevar o nível da educação feminina, "polir o espírito". Aparelhada e habilitada, terá condições de prover sua situação econômica, sair da rotina, da "atitude burguesa acomodatícia e passiva", ${ }^{72}$ tomar parte da grande luta que embeleza a vida, conquistar seus ideais, entrar "no gozo dos seus direitos sem choque com os direitos do homem". ${ }^{73}$

Como se pode avaliar, esses discursos falam de um novo enunciado em torno das mulheres e sobre elas. São incendiários, buliçosos. Essa sociedade não ficaria incólume aos desejos das mulheres de conquistar outros patamares políticos, sociais e culturais. O paradoxo de sua fala era emblemático ao sistema republicano oligárquico. A liberdade de expressão e de posicionamento dessas feministas forçou o avanço e o alargamento do sistema tão pouco democrático.

Essas palavras soaram os clarins do confronto. Algumas mulheres feministas, essas que haviam conquistado formação superior, uma profissão e um salário, que haviam enfrentado as humilhações, a disputa desleal, os preconceitos de uma 
${ }^{74}$ SCOTT, 2002, p. 19.

${ }^{75}$ ARQUIVO NACIONAL..., 1930, p. 3-4, apud ARQUIVO NACIONAL..., 1931 p. $4-5$. sociedade machista, sabiam que a possibilidade de mudança estava na autonomia financeira das mulheres. Mas como alcançá-la? Como elevar as outras mulheres a esses patamares? Só o acesso à educação profissionalizante poderia promover esse deslocamento e empoderamento feminino. Como almejar autonomia, independência, liberdade para a mulher, sem pretender se chocar com o poder dos homens, dos machos, sejam eles maridos, irmãos ou filhos? Eis as encruzilhadas do movimento. Como ressalta Joan Scott, as feministas transitavam entre a "aceitação e recusa simultâneas [que] punham a nu as contradições e omissões nas definições de gênero que eram aceitas em nome da natureza e impostas por lei". ${ }^{74}$

Ida Souto lançou a plataforma de ações da Federação Pernambucana, repetindo ipsis litteris o que a Nacional estabeleceu:

1. Promover a educação da mulher e elevar o nível da instrução feminina; 2. Proteger as mães e a infância; 3. Obter as garantias legislativas e práticas para o trabalho feminino; 4. Auxiliar as boas iniciativas da mulher e orientá-las na escolha de uma profissão; 5. Estimular o espírito de solidariedade e da cooperação entre as mulheres e interessá-las pelas questões sociais e de alcance público; 6. Assegurar à mulher os direitos políticos e prepará-la para o exercício inteligente desses direitos; 7. Estreitar os laços de amizade com os demais países americanos, a fim de garantir a manutenção perpétua da paz e da justiça no Hemisfério Ocidental. ${ }^{75}$

Apenas no item 6 é expressamente colocada a questão dos direitos políticos, como se a noção de cidadania escapasse da esfera estritamente política, ganhasse outras arenas - da educação, dos direitos trabalhistas, da maternidade.

Sob forte pressão dos movimentos feministas organizados, e a fim de atender a uma das principais reivindicações da Aliança Liberal, Getúlio Vargas, como chefe do Governo Provisório, nomeou uma comissão para criar uma nova lei eleitoral. Pelo Decreto n. 21.076, de 24 de fevereiro de 1932, o novo Código Eleitoral Brasileiro concedia o direito político às mulheres, no mesmo molde do direito dos homens, isto é, a maiores de 21 anos e alfabetizadas. Deve-se lembrar que o alistamento e o ato de votar não eram obrigatórios. Essa inovação precisava ser incorporada à Constituição a ser elaborada.

Apesar da festa e das congratulações iniciais, as propaladas conquistas estavam ainda sob terreno frágil e contingencial. A campanha sufragista não conseguiu envolver nem alcançar a maior parcela das mulheres - as que pertenciam

54 Estudos Feministas, Florianópolis, 21(1): 41-57, janeiro-abril/2013 
${ }^{76}$ BESSE, 1999, p. 196.

às camadas populares e operárias -, que não teve acesso à instrução e ficou excluída dessa conquista. Sem dúvida, o ingresso na educação superior e a obtenção de uma profissão eram aspirações para mulheres de classe média e alta, mas irrelevantes para a maioria das mulheres pobres e analfabetas, como afirma Susan Besse. Mas não se pode olvidar que, mesmo limitado, o movimento significou um momento da luta feminista, em que essas mulheres acreditaram na via política partidária. Sonharam que, uma vez no poder legislativo, poderiam alcançar conquistas importantes na esfera social e civil. Nesse sentido, acreditaram na via liberal, normativa e sem confrontos abertos. Era um caminho... longo, árduo e, talvez, apenas para algumas gerações.

Assim, concordo com Susan Besse, quando ela diz que, se a Federação Brasileira houvesse se misturado com a política de classe, numa sociedade extremamente conflitiva e tão marcada pelas diferenças de classe, isso teria sido intolerável. ${ }^{76} \mathrm{Em}$ nível nacional e local, o movimento sufragista foi mesmo elitista e limitado.

No entanto, foram essas mulheres de famílias abastadas e de classe média que conseguiram levar adiante o debate e enfrentar, com risos e lágrimas, os chistes, as charges, as caricaturas, as piadas e uma imprensa ofensiva. Foram elas também que terminaram politizando a discussão da exclusão feminina da arena política, ao questionar a desigualdade de direitos entre os sexos. Nem sempre foram coerentes. Aceitaram e negaram ao mesmo tempo a diferença presa ao sexo, ao corpo, ao biológico. Se não combateram a naturalização da diferença, questionaram seus pressupostos e desnudaram a profunda e entranhada concepção de inferioridade das mulheres diante dos homens. Assim, a via partidária, como estratégia de luta, não foi exclusiva. As feministas colocaram em campo as táticas de convencimento, as alianças políticas e familiares, a utilização da imprensa falada e escrita e, por vezes, tiveram duros enfrentamentos e embates com os poderes estabelecidos, com parte da sociedade da época, incrédula e arredia. Enlaçaram as práticas da liberdade e da amizade. Pegaram o moderno bonde e fizeram os percursos do desejo. Ousaram.

\section{Referências}

ALVES, Branca Moreira. Ideologia e feminismo: a luta da mulher pelo voto no Brasil. Petrópolis: Vozes, 2000.

ALVES, Branca Moreira; PITANGUY, Jacqueline. O que é feminismo. São Paulo: Brasiliense, 1985.

ANDRADE, Manuel Correia. Pernambuco imortal: evolução histórica e social de Pernambuco. Recife: Ed. CEPE, 1997. 
A NOTíCIA. Recife, 7 nov. 1927; 14 dez 1927; 15 dez 1927; 27 dez 1927; 28 dez 1927; 31 maio 1931; 2 jun 1931; 7 jun 1931; 6 nov. 1931; 11 nov. 1931; 12 nov. 1931; 31 nov. 1931.

ARQUIVO NACIONAL DO RIO DE JANEIRO. Estatuto da Federação Brasileira para o Progresso Feminino. Rio de Janeiro: Fundo FBPF/Oficinas Gráficas do Jornal do Brasil, 1930.

Relatório da Federação Pernambucana para o Progresso Feminino. Recife: Fundo FBPF, 31 maio 1931-30 set. 1933.

. Discurso de Ida Souto Uchôa na solenidade de criação da FPPF. Recife: Fundo FBPF, 10 nov. 1931.

BESSE, Susan K. Modernizando a desigualdade: reestruturação da ideologia de gênero no Brasil, 1914-1940. São Paulo: EDUSP, 1999.

BOBBIO, Norberto. Teoria geral da política. 20. ed. Rio de Janeiro: Elsevier, 2000.

BRASIL. Código Civil dos Estados Unidos do Brasil. Leis, decretos etc. 1916.

DIÁRIO DE PERNAMBUCO. Recife, 30 out. 1985, seção B, p. 1.

DONZELOT, Jacques. A polícia das famílias. 2. ed. Rio de Janeiro: Graal, 1986.

FOUCAULT, Michel. Ditos e escritos: ética, sexualidade, política. Rio de Janeiro: Forense Universitária, 2004. v. 5.

FUNDAJ. Notas Bio-bibliográficas de Edwiges de Sá Pereira. Acervo pessoal. Recife, s/d.

HAHNER, June E. Emancipação do sexo feminino: a luta pelos direitos da mulher no Brasil, 1850-1940. Florianópolis: Ed. Mulheres; Santa Cruz do Sul: Edunisc, 2003.

INTHERTESIS. Florianópolis, v. 4, n. 1, jan./jun. 2007. Disponível em: www.periodicos.ufsc.br/index.php/interthesis/article/ .../911/10852. Acesso em: 26 abr. 2012.

GAY, Peter. A experiência burguesa da Rainha Vitória a Freud: a educação dos sentidos. São Paulo: Cia. das Letras, 1988.

GOMES, Ângela de Castro. "Escrita de si, escrita da História: a título de prólogo". In: GOMES, Ângela de Castro (Org.). Escrita de si, escrita da História. Rio de Janeiro: FGV, 2004. p. 7-24.

PEREIRA, Edwiges de Sá. Pela Mulher, para a Mulher. Recife: Officinas Graphicas da Associação da Bôa Imprensa, 1932.

PERROT, Michelle. As mulheres ou os silêncios da história. Bauru, SP: EDUSC, 2005.

PINTO, Céli Regina Jardim. Uma história do feminismo no Brasil. São Paulo: Fundação Perseu Abramo, 2002.

RAGO, Margareth L. "Adeus ao feminismo. Feminismo e (pós)modernidade no Brasil". Cadernos AEL, n. 3/4, p. 1 33, 1995/1996. Disponível em: http://www.ifch.unicamp.br/ ael/website-ael_publicacoes/cad-3/Artigo-1-p11.pdf. Acesso em: abr. 2011.

56 Estudos Feministas, Florianópolis, 21 (1): 41-57, janeiro-abril/2013 
REZENDE, Antônio Paulo. Recife: histórias de uma cidade. Recife: Fundação de Cultura da Cidade do Recife, 2002.

SCHUMAHER, Shuma; BRAZIL, Érico Vital (Orgs.). Dicionário Mulheres do Brasil. Rio de Janeiro: Zahar, 2000.

SCOTT, Joan. A cidadã paradoxal: as feministas francesas e os direitos dos homens. Florianópolis: Ed. Mulheres, 2002.

SEVCENKO, Nicolau. "A capital irradiante". In: NOVAIS, Fernando (Coord. geral); SEVCENKO, Nicolau (Coord. do volume). História da vida privada no Brasil. São Paulo: Cia. das Letras, 1998. v. 3. p. 513-619.

SOIHET, Rachel. Feminismo tático de Bertha Lutz. Florianópolis: Ed. Mulheres, 2006.

VAINSENCHER, Semira Adler. Estácio Coimbra. Disponível em: http://www.fundaj.gov.br/notitia/servlet/newstorm.ns.presen tation. NavigationServlet?publication Code $=16$ \&page Code $=302 \&$ textCode $=799 \&$ date $=$ current Date. Acesso em: abr. 2011.

VERFUS, Anne. "Voto familiarista e voto familiar: contribuição para o estudo do processo de individualização das mulheres na primeira metade do século XIX". In: CANÊDO, Letícia Bicalho (Org.). O sufrágio universal e a invenção democrática. São Paulo: Estação Liberdade, 2005. p. 405-433.

[Recebido em setembro de 2011 , reapresentado em maio de 2012 e aceito para publicação em maio de 2012]

The Streetcar of Desire: The Feminist Movement in Recife and the Debate about Sexism in Republican Politics (1927-1931)

Abstract: This article investigates how the Feminist Movement in Recife problematized the silence and denial of political rights to women in the First Republic. Strategically, feminists have focused on the conquest of political rights, as the possibility of achieving equal civil and social rights. The intense use of the press, radio and the creation of newspapers and magazines tell about feminist practices of freedom and power games, which seek to redefine the relationship of gender within the framework of a democratic and republican regime. If the movement did not fight against the naturalization of the difference between genders, it questioned its assumptions and laid bare the deep and ingrained concept of women's inferiority before men. The feminists took the modern streetcar and made the paths of desire.

Key Words: Feminisms; Feminist Movement; Gender Relations; Citizenship. 